\title{
In de h200d: een eigentijdse etnografie
}

\author{
R.A. Roks*
}

Juan: ‘Twitter tripple OG’S’ (11-08-2013 17:06)

Fernando: @Juan: ‘hahahah Rollin Twitter Crips' (11-08-2013 17:10)

De bovenstaande 'tweets' zijn afkomstig van twee jongeren die ik in het kader van het veldwerk voor mijn promotieonderzoek vanaf 2011 tot en met 2013 heb gevolgd. Juan en Fernando, twee gefingeerde namen, hebben allebei deel uitgemaakt van de Rollin 200 Crips, een Nederlandse 'gang' naar Amerikaans voorbeeld die sinds de jaren negentig in de media geregeld van zich heeft laten horen. ${ }^{1}$ Hun tweets verwijzen naar de toenemende virtualisering van de Nederlandse straatcultuur. OG, oftewel 'Original Gangster', is slang die afkomstig is uit de Verenigde Staten, maar als gevolg van de mondiale verspreiding van Amerikaanse gang- en straatstijlen ook onderdeel is geworden van het vocabulaire van jongeren in Nederland. Op Twitter wordt volgens Juan geclaimd dat mensen 'Tripple OG' zijn: een term die gebruikt wordt als verwijzing naar een hoge hiërarchische en respectabele positie op straat. Fernando lacht uitbundig om de opmerking van Juan en maakt van Rollin 200 Crips de 'Rollin Twitter Crips', implicerend dat de activiteiten van de Crips zich in toenemende mate op social media afspelen.

In deze bijdrage wil ik laten zien dat social media een relatief onontgonnen bron van criminologisch relevante data kunnen opleveren. In het bijzonder wil ik daarbij het belang van deze online praktijken illustreren voor eigentijds etnografisch onderzoek. Ten slotte sta ik stil bij de ethische dilemma's en beperkingen die gepaard gaan met het

* Drs. Robby Roks is als universitair docent verbonden aan de sectie Criminologie van de Erasmus Universiteit Rotterdam.

1 O.a. in de documentaire Strapped ' $n$ strong uit 2009 (te bekijken via: www.npo.nl/cripsstrapped-n-strong/POMS_S_BNN_097359), maar ook in het boek Crips.n/van Saul van Stapele (Van Stapele 2003) en diverse artikelen in het tijdschrift Nieuwe Revu (o.a. Van Stapele 1998; 2009). 
gebruik van deze nieuwe, andersoortige methoden van dataverzameling.

\section{Etnografisch onderzoek}

Sinds de Chicago School kent etnografisch onderzoek een stevige verankering in de historie van de criminologie. Door de jaren heen lijkt er een wisselende belangstelling te bestaan voor deze onderzoeksbenadering, mede als gevolg van discussies over ethiek (Adler \& Adler 1998) en het tijdsintensieve proces van dataverzameling. In toenemende mate wordt echter gewezen op de meerwaarde van dit methodologische perspectief voor de criminologie (Ferrell \& Hamm 1998), ook in Nederland (Schuilenburg e.a. 2011, p. 13-14).

Etnografisch onderzoek vormt niet zozeer een methode van onderzoek, maar dient gezien te worden als een onderzoeksbenadering die meerdere methoden behelst. Naast participerende observatie, wordt veldwerk gekenmerkt door het gebruik van diverse methoden en technieken, zoals interviewen, maar ook het verzamelen en analyseren van allerlei persoonlijke documenten. De kern van het verrichten van etnografisch veldwerk is gelegen in het 'being there': het langdurig deelgenoot worden van een gemeenschap, cultuur of setting om deze leefwereld van binnenuit te begrijpen en te beschrijven (Zaitch e.a. 2010, p. 262-274). Er valt een aantal ontwikkelingen waar te nemen die inwerken op het centrale uitgangspunt van 'being there'. Allereerst hebben processen van mondialisering invloed op de betekenis die wordt gehecht aan de notie van lokaliteit (Wittel 2000). Hannerz pleit om die reden voor zogenaamde 'multi-sited ethnographies' om recht te doen aan het feit dat personen, verhalen en objecten steeds mobieler worden (Hannerz 2003). Een hieraan verwante ontwikkeling betreft de komst van het internet en de toenemende virtualisering van het dagelijks leven.

Het internet biedt voor onderzoekers interessante uitdagingen, vooral in methodologische zin. Ook binnen de criminologie is aandacht voor het gebruik van internet bij het verrichten van kwalitatief onderzoek (vgl. Flick 2010). In een themanummer van het Tijdschrift voor Criminologie (2013) wordt daarbij onder andere gewezen op het gebruik van online dader- en slachtofferenquêtes, de opkomst van Big Data, digitale of virtuele vormen van participerende observatie of het gebruik 
van computertechnologie als aanvullend hulpmiddel waarmee respondenten aan virtuele situaties kunnen worden blootgesteld (Van Erp e.a. 2013, p. 332-333). Wat opvalt wanneer de mogelijkheden van de gedigitaliseerde wereld worden verkend, is dat er over het algemeen een (te) strikte scheiding wordt aangebracht tussen het verrichten van online en offline onderzoek. Het is de vraag of een dergelijke binaire scheiding voldoende recht doet aan de werkelijkheid (vgl. o.a. Leander \& McKim 2003; De Jong \& Schuilenburg 2006; Murthy 2008; Ferrell e.a. 2015). Online en offline praktijken raken immers in toenemende mate verweven met elkaar, een ontwikkeling die nadrukkelijke consequenties heeft voor het 'being there'. Etnografisch onderzoek zou anno 2016 niet enkel aandacht moeten hebben voor wat respondenten offline doen en zeggen, maar tevens proberen te incorporeren wat zij online doen en zeggen. De mogelijkheden en moeilijkheden die daarmee gepaard gaan, wil ik illustreren aan de hand van mijn veldwerk 'in de h200d' (Roks 2016).

\section{Offline in de h200d}

Het startpunt voor mijn onderzoek naar de inbedding van criminaliteit en identiteit was een kleine wijk in Den Haag, die in de volksmond bekendstaat als het Vergeten Dorp. Sinds eind jaren tachtig van de vorige eeuw claimen de Haagse Crips deze buurt als hun territorium en noemen ze het hun 'h200d'. ${ }^{2}$ In januari 2011 begon ik mijn veldwerk in de h200d met het intensiveren van de contacten die ik daar had opgedaan in een eerder onderzoek (Roks 2007). Omdat mijn gatekeeper Keylow, de leider en oprichter van deze Haagse Crips, op dat moment in detentie verbleef, zocht ik naar plekken in de buurt waar het sociale leven zich afspeelt. In navolging van anderen (o.a. Van Gemert 1998; De Jong 2007) begon ik in het lokale buurthuis. Daar bezocht ik, na overleg met de jongerenwerker, een paar keer per week de inloop van het jongerenwerk. Ongeveer vijftig jongeren tussen de 12 en 20 jaar uit het Vergeten Dorp en omringende buurten kwamen daar op vaste tijden bijeen in een kleine ruimte van het buurthuis.

2 'H200d' (uitgesproken als 'hood') vormt een verbastering van het Engelse 'neighborhood'. Het vervangen van de letters ' $O$ ' in het woord door het getal '200' vormt een verwijzing naar de volledige naam van deze Haagse Crips, de Rollin 200 Crips. Het gebruik van de term 'h200d' dient te worden gezien als een manier waarmee de Rollin 200 Crips de fysieke ruimte van het Vergeten Dorp claimen als hun territorium. 
Omdat deze inloop alleen werd bezocht door jonge buurtbewoners, besloot ik ook contact te zoeken met de actieve bewonersorganisatie die het Vergeten Dorp van oudsher kent. Een halfjaar en een flink aantal e-mails later kwam ik in contact met de voorzitter en penningmeester en werd ik uitgenodigd om de maandelijkse vergaderingen van de bewonersorganisatie bij te wonen.

Toen Keylow een halfjaar na de start van mijn veldwerk weer in vrijheid werd gesteld, besloot ik meer te investeren in het opbouwen van relaties met leden van de Crips. Een direct gevolg hiervan was dat ik minder tijd stak in het onderhouden en uitbouwen van contacten met jongeren uit de buurt en oudere buurtbewoners. Omdat het buurthuis bovendien in de zomermaanden gesloten bleef, zorgde dit voor een extra complicerende factor voor mijn relaties met jongeren uit de buurt. Ook het contact met de Crips verliep in het begin moeizaam, ook al had ik al enkele jaren geleden het vertrouwen van mijn gatekeeper Keylow weten te winnen. Bij afwezigheid van Keylow in de h200d werd ik niet gegroet en op tijden zelfs opzichtig genegeerd wanneer ik een gesprek probeerde aan te knopen. Het duurde bij sommige respondenten meer dan een jaar, waarin ik de buurt meermaals per week bezocht, voordat ze mijn aanwezigheid in hun nabijheid tolereerden en mij actief betrokken in gesprekken. Na een jaar waarin vooral de nadruk op observeren lag en ik bewust niemand van de Crips heb geïnterviewd, was ik gedurende de zomermaanden van 2012 in staat om mezelf te midden van de Crips te begeven. Langzaamaan begon ik met het systematisch verzamelen van informatie over de individuele leden van de Crips. Mijn rol verschoof hierbij gradueel richting participerende vormen van onderzoek in de vorm van gezamenlijke sportactiviteiten en het luisteren van muziek, maar hoofdzakelijk het hele dagen rondhangen in de h200d.

Het leggen van contacten in het buurthuis verliep in het begin eveneens uiterst moeizaam. Tijdens mijn bezoeken aan het buurthuis trof ik dezelfde jongeren die ik eerder in 2007 had gezien in de buurt, maar die toen nog hooguit 10 of 11 jaar waren. Bovendien herkende ik een deel van de bezoekers van het buurthuis van gezicht omdat zij naar voren komen in de documentaire Strapped ' $n$ strong (2009) over de Rollin 200 Crips. Naarmate ik vaker in het buurthuis kwam, werd het contact met sommige jongeren beter. In de periode dat ik meer tijd op straat met de Crips doorbracht, zag ik deze jongeren echter steeds 
minder. Slechts sporadisch trof ik ze nog op straat of in de wijk en het contact met een deel van hen dreigde te verwateren.

\section{Online in de h200d}

Tijdens mijn eerste bezoeken aan de inloop sprong in het oog hoezeer de jongeren gebruik maakten van sociaalnetwerksites als Hyves en Twitter via de internetverbinding op de vaste computers in het buurthuis of op hun mobiele telefoons. Op momenten dat ik niet in het Vergeten Dorp of in het buurthuis was, probeerde ik de jongeren online te vinden. Een probleem daarbij was dat lang niet iedereen onder zijn of haar eigen naam actief is op social media. Na het nodige zoekwerk en het systematisch doorzoeken van zogenaamde 'followlijsten' en hun online 'vrienden' vond ik het grootste deel van de jongeren uit de buurt online. Uiteindelijk heb ik van veertig jongere respondenten die actief gebruik maken van social media als Twitter, Facebook en Instagram gedurende drie jaar hun online activiteiten gemonitord, opgeslagen en geanalyseerd.

Social media bieden mogelijkheden voor verschillende rollen, analoog aan de methode van participerende observatie in bredere zin. De nadruk tijdens mijn bezoeken aan de inloop in het buurthuis lag op observeren. Onder de noemer 'lurking' (Leander \& McKim 2003) of 'cyberstealth' (Murthy 2008) is dit ook mogelijk online. De socialmedia-accounts van de jongeren uit de buurt bevatten een scala aan relevante informatie. Demografische gegevens, zoals leeftijd, afkomst en woonplaats, waren te vinden op de openbare profielen. Op 'timelines' op Twitter stond daarnaast informatie over school, bijbanen, werk, hobby's en andere activiteiten in hun vrije tijd. De interactie tussen jongeren op social media leerde mij bovendien veel over welke jongeren met elkaar in contact staan en online veel contact met elkaar onderhouden.

Door het volgen van hun online praktijken op social media kreeg ik op een eenvoudige manier veel te weten over deze jongeren. Enigszins tot mijn verbazing stuitte ik op social media bovendien op informatie waarvan ik op voorhand niet direct had verwacht deze online te vinden. In het buurthuis en op straat gingen gesprekken tussen jongeren onderling geregeld over hun criminele betrokkenheid of hun aanrakingen met politie. In het begin vonden dergelijke conversaties niet in 


\section{Figuur 1}

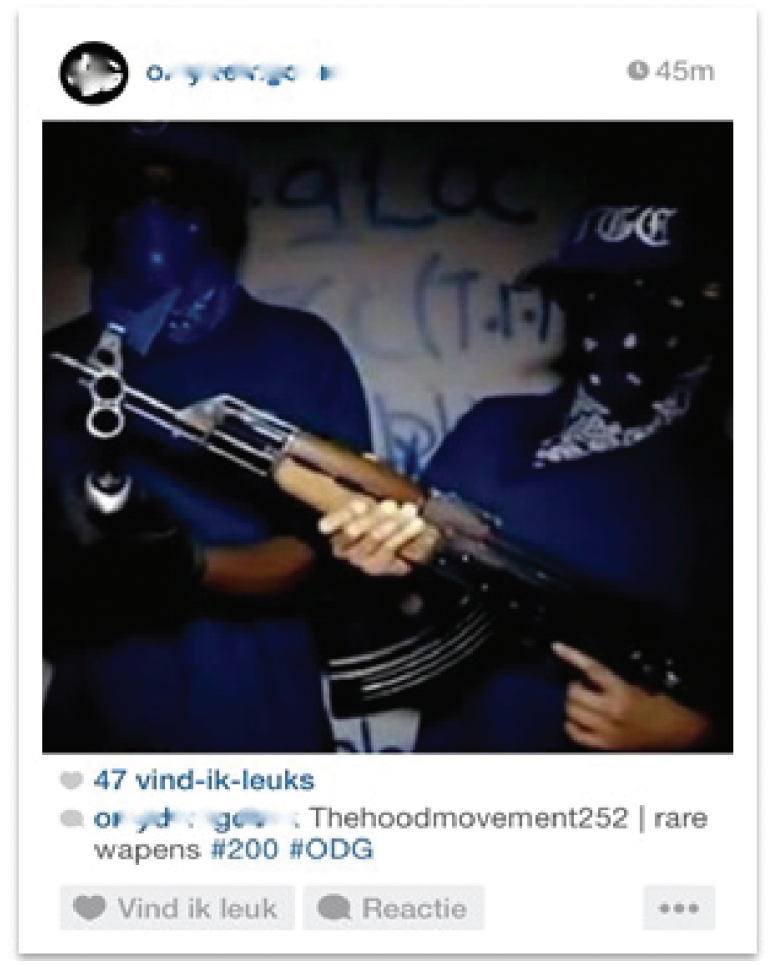

mijn aanwezigheid plaats en vielen jongeren stil of deden ze geheimzinnig wanneer ik in staat was om delen van een gesprek op te vangen. Met de jongeren sprak ik hoofdzakelijk over meer neutrale onderwerpen, in het bijzonder omdat ik door enkele jongeren uitgemaakt was voor 'po-po' of ‘scotoe'. Dezelfde jongeren leken op social media veel minder bezig met het afschermen van hun activiteiten op straat. Sterker nog: social media werden expliciet gebruikt om de indruk te wekken van criminele betrokkenheid.

Het eerste thema dat op social media valt waar te nemen, is geweld, in het bijzonder in de vorm van het tonen van (vuur)wapens of kogels (zie figuur 1 en 2). 


\section{Figuur 2}

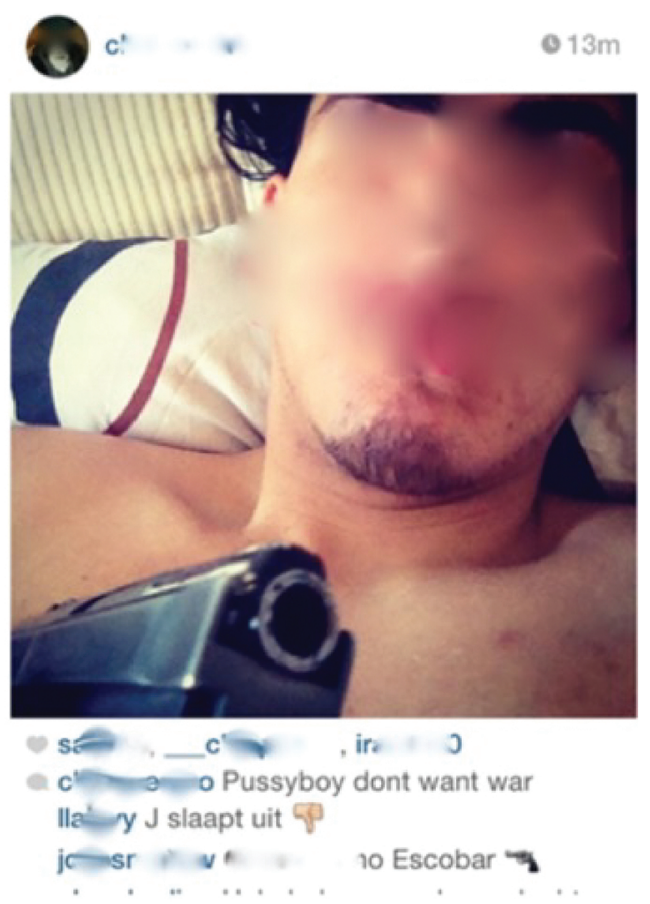

Figuur 1 is een beeldfragment dat afkomstig is uit de documentaire Strapped 'n strong (2009), waarop twee jongeren uit de buurt, gehuld in de voor de Crips kenmerkende blauwe kledingstijl, een volautomatisch machinegeweer dragen. Het onderschrift 'hoodmovement' verhult bovendien de mate van trots en identiteit die ontleend wordt aan het feit dat de jongen afkomstig is uit de wijk waar de Crips hun wortels hebben. Ondanks de symboliek van de Crips die hier gecommuniceerd wordt, maakt de jongen in kwestie geen onderdeel uit van de Rollin 200 Crips. Sterker nog: tijdens mijn onderzoek stond hij lange tijd op gespannen voet met enkele jongere leden van de Crips.

Figuur 2 is een voorbeeld van een post waarop een vuurwapen wordt getoond. Er bestaan hierbij verschillen tussen jongeren wat betreft 


\section{Figuur 3}

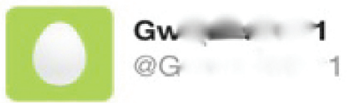

\section{In me zak heb ik een bom pic.twitter.com/du2bVeP $3 \mathrm{H}_{2}$}

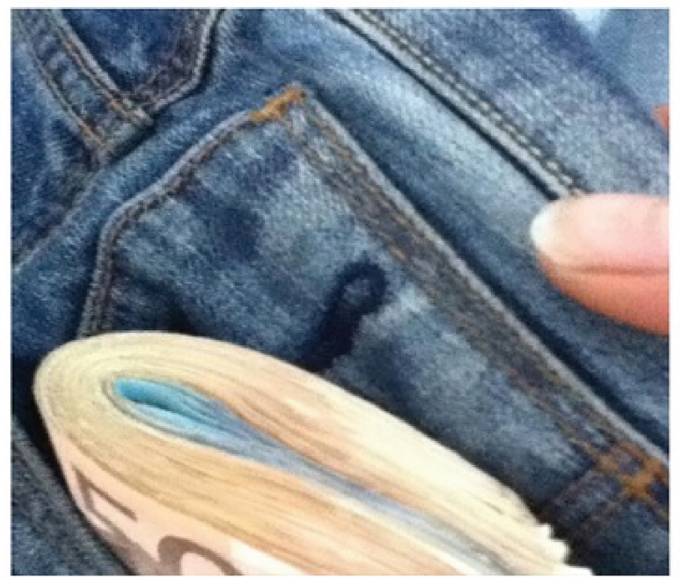

hun herkenbaarheid wanneer ze afbeeldingen met vuurwapens of kogels plaatsen op social media. Gedurende mijn veldwerk viel hierin een ontwikkeling waar te nemen en verschenen de jongeren steeds minder met hun gezicht in beeld. Deels was dit het gevolg van verhalen die er op straat verteld werden over jongeren die door de politie opgepakt werden vanwege het posten van dergelijke foto's. Bovendien bleven afbeeldingen met vuurwapens over het algemeen slechts een beperkte tijd online staan en werden ze vaak nog dezelfde dag, nadat de foto's tientallen likes hadden gekregen, weer verwijderd.

Een tweede veelvoorkomend thema betreft het tonen van grote hoeveelheden contact geld. Railey toont op figuur 3 dat hij in zijn zak een 'bom' heeft bestaande uit diverse gekleurde bankbiljetten. 


\section{Figuur 4}

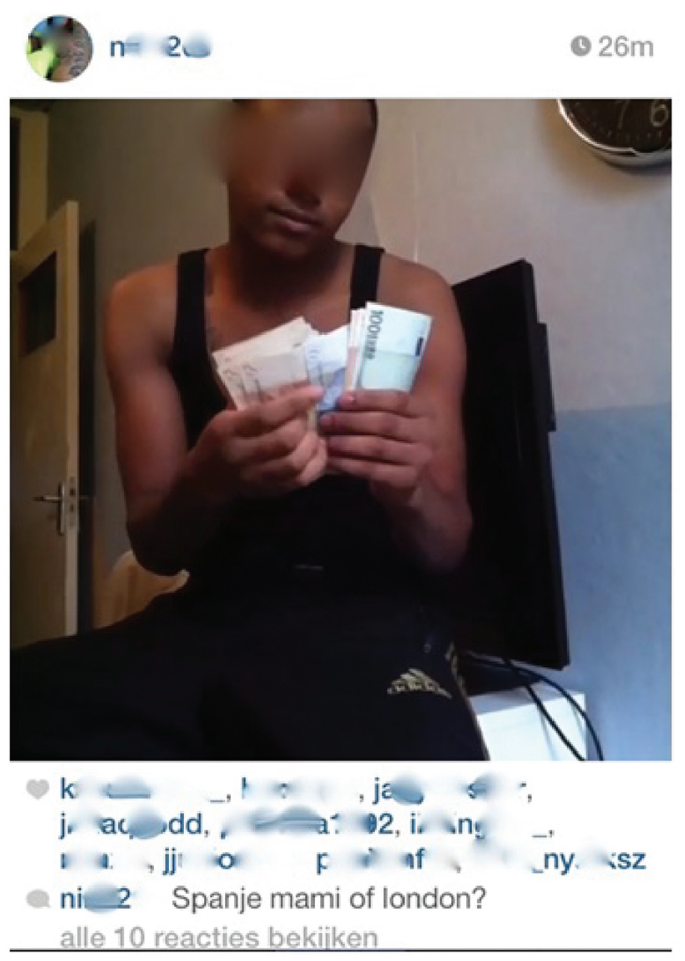

Reynaldo plaatste een video op Instagram, waarvan figuur 4 een snapshot vormt, waarop hij gedurende enkele seconden demonstratief een stapel geld aan het tellen is. Naast het tentoonspreiden van hun weelde, laat een deel van deze jongeren er op social media geen misverstand over bestaan wat de herkomst van deze verdiensten is. In tweets bieden zij onder andere scooters, televisies, tablets of telefoons te koop aan, maar wordt er eveneens geadverteerd met diensten op het gebied van de verkoop van drugs.

Social media worden ook gebruikt om uitdrukking te geven aan het feit dat de politie op straat beschouwd wordt als 'de natuurlijke vijand' 
(De Jong 2007, p. 67). Met tweets als 'Fuck the Cops', 'Fucc a popo' en 'Fuck de 5'0'3 presenteren sommige jongeren op wekelijkse basis - en een enkeling zelfs dagelijks - hun aversie tegen de politie. Een enkeling heeft dit in de vorm van een tatoeage met 'FTP' - oftewel Fuck The Police - zelfs vereeuwigd op zijn lichaam. Een specifiek thema waarin de relatie met de politie naar voren komt, is 'snitchen': het geven van belastende verklaringen bij de politie over anderen, onder andere tijdens verhoren (Roks 2015). Naast scheldkanonnades richting het adres van politie, plaatsen de jongeren foto's online van vrienden die staande worden gehouden, worden gearresteerd, vrienden die vastzitten en zich laten fotograferen tijdens hun gevangenisstraf van achter de tralies (figuur 5), en ook verdachte vrienden worden tijdens rechtszaken in de beklaagdenbank op de gevoelige plaat vastgelegd.

\section{Figuur 5}

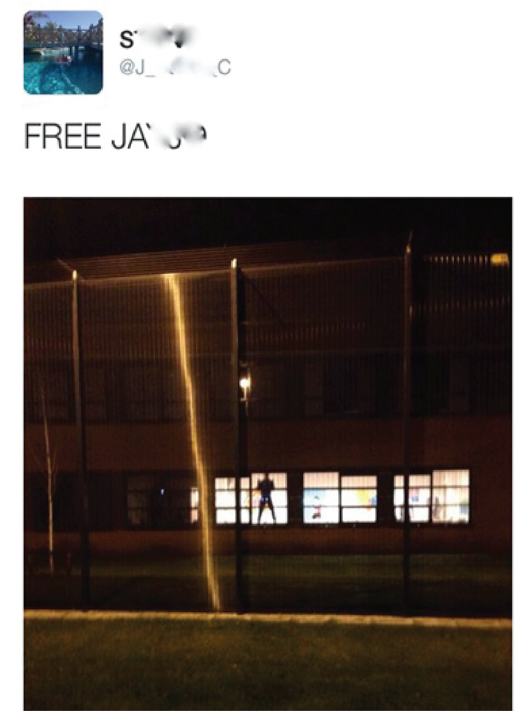

Ook de afwikkeling van strafzaken valt online te volgen. Zo doet Jack eigenhandig verslag van zijn rechtszaak. Hij begint op 11 mei 2011 met

3 Over de ontstaansgeschiedenis van deze denigrerende termen voor de politie doen op internet diverse verhalen de ronde (http://en.wikipedia.org/wiki/List_of_police-related_ slang_terms). Door populaire Amerikaanse films, series en (rap)muziek hebben deze termen een mondiale verspreiding gekregen. 
de tweets 'Dood zenuw8tig main', gevolgd door 'Morgen voorkomen'. Een dag later brengt hij uitvoeriger verslag uit:

‘@paleis van justesie’ (12-05-2011 08:49)

'Fuck rechtzaken' (12-05-2011 09:55)

'Fuck werk school allleS !' (12-05-2011 09:55)

'Nu rechtzaak' (12-05-2011 10:33)

'Nu w8ten op uitspraak' (12-05-2011 11:14)

'Vrij kkk gesproken mossssssss !!!!!!!!!!!!!!!!!!!!' (12-05-2011 13:00)

'Moss eerst 90 dagen zitten nu gewooon vrygesproken' (12-05-2011 13:08)

De eerdergenoemde Fernando plaatst eerst 'OMW rechtzaak', om vervolgens figuur 6 op Instagram te plaatsen. De foto, genomen voor het Paleis van Justitie in Den Haag, is zo bewerkt dat er staat 'Eis van Justitie', terwijl de print op de rode trui van Fernando leest: 'FOKDEMCOPS'.

Naast inhoudelijk relevante informatie bieden social media eveneens mogelijkheden tot het benaderen en werven van respondenten. Zo werden telefoonnummers en e-mailadressen genoemd in berichten, geplaatst onder afbeeldingen of gepubliceerd op gebruikersprofielen. Daarnaast maakten veel jongeren gebruik van social media om met elkaar af te spreken. Op die manier kreeg ik zicht op locaties in de stad of buurt waar respondenten zich bevonden of openbare plekken waar zij veel tijd doorbrachten. Bovendien bieden diverse sociaalnetwerksites functies die gebruikers in staat stellen om privéberichten of een zogenaamde 'DM' (Direct Message) te sturen. Deze mogelijkheden gebruikte ik om af te spreken met jongeren die ik offline langere tijd niet had gezien of die ik wat langer een-op-een wilde spreken. Toch was deze laagdrempelige manier van het leggen van contacten niet altijd even succesvol en heeft een aantal respondenten nooit gereageerd op mijn verzoeken, ondanks herhaaldelijke berichten. In die gevallen probeerde ik hen offline te benaderen. ${ }^{4}$

4 Ook offline verliep het benaderen van respondenten niet zonder problemen. De centrale bevindingen in mijn proefschrift baseer ik op een netwerk van 150 respondenten. Van zestig van deze respondenten heb ik gedetailleerde informatie verzameld, ofwel op basis van één (of meerdere) interview(s), ofwel omdat ik ze gedurende drie jaar meermaals op informele basis heb gesproken en heb geobserveerd. 


\section{Figuur 6}
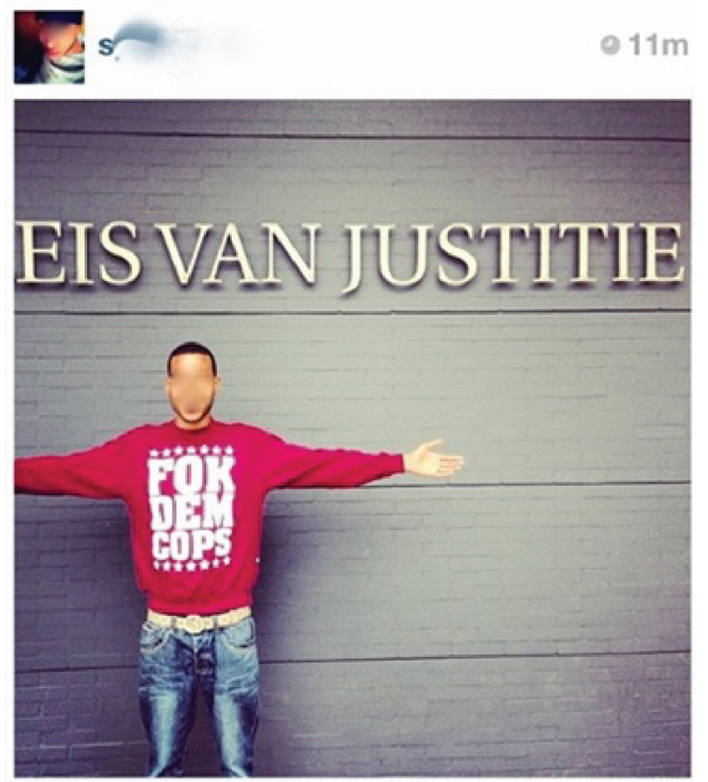

12 vind-ik-leuks

as iv \#eisvanjustitie \#FOKDEMCOPS

rs a Hahaha this men

ke _ Wahahah (80)

\section{Beperkingen en dilemma's: selectie, het gebruik van beelden en performance}

Social media bieden diverse mogelijkheden voor criminologisch onderzoek, maar het gebruik van deze data dwingt ook tot een reflectie op de beperkingen en brengt bovendien een aantal ethische dilemma's met zich mee. Een aantal van deze methodologische vertekeningen is vergelijkbaar met de problemen en dilemma's die inherent zijn aan de meer klassieke, offline kwalitatieve methoden. Etnografisch onderzoek kent als evident nadeel dat de nadrukkelijke aanwezigheid van de onderzoeker en zijn of haar 'selectieve oog' invloed kunnen hebben op de resultaten van de studie. Naast de beperkte externe validiteit, gaat het gebruik van deze onderzoeksbenadering 
gepaard met diverse morele, juridische en ethische dilemma's (Zaitch e.a. 2010, p. 282-284). De toevoeging van een online dimensie aan offline praktijken roept een aantal nieuwe vragen op.

De eerste beperking ten aanzien van online vormen van kwalitatief onderzoek betreft selectiviteit. Tussen de respondenten in mijn studie bleek een verschil te bestaan in de mate waarin zij actief waren op social media. Vrijwel iedere jongere maakte gebruik van (meerdere) social media en plaatste dagelijks meerdere foto's of berichten. De online praktijken van respondenten boven de 30 vielen veel minder goed waar te nemen. ${ }^{5}$ Daarnaast bestond er een duidelijk verschil tussen welke informatie online werd geplaatst. Sommigen plaatsten allerlei facetten van hun dagelijks leven online, inclusief (de suggestie van) hun criminele betrokkenheid, terwijl anderen zich beperkten tot het reageren op berichten en foto's van anderen. Als onderzoeker heb ik hierdoor (slechts) zicht gekregen op een deel van de activiteiten van deze veertig respondenten op social media. Dit geldt overigens eveneens voor de offline praktijken van mijn respondenten: ondanks dat ik getracht heb zo veel mogelijk deelgenoot te worden van hun dagelijks leven, is er onherroepelijk een deel aan mijn oog onttrokken gebleven. Het is immers onmogelijk om altijd en overal in het veld aanwezig te zijn. Daarnaast hebben respondenten, ongeacht hoe hecht of vriendschappelijk onze relatie in de loop der jaren werd, ook altijd een deel van hun leven voor mij weten af te schermen.

Een bijkomende uitdaging op social media was dat jongeren zich in toenemende mate ${ }^{6}$ bewust leken van hun zichtbaarheid en privacy op internet en zodoende hun profielen en accounts afschermden met de mogelijkheden die sociaalnetwerksites daartoe bieden. Om toch toegang te krijgen tot de inhoud van iemands online profiel of timeline, dient dan een vriendschaps- of volgverzoek te worden verstuurd. Aan de veertig respondenten die ik op social media gedurende drie jaar heb gevolgd, heb ik allemaal een vriendschaps- of volgverzoek verstuurd. ${ }^{7}$ Op een enkel geval na werden deze verzoeken vrijwel direct geaccepteerd, naar alle waarschijnlijkheid omdat ik hen, op een enke-

5 Wel viel er een opmerkelijke gelijkenis waar te nemen tussen wat jongere respondenten op social media plaatsten en de profielfoto's op BlackBerry 'Ping' en WhatsApp van oudere respondenten.

6 Rond de start van mijn veldwerk was hier nauwelijks sprake van. Tegen het einde van mijn onderzoek leken respondenten echter veel meer gebruik te maken van de mogelijkheden die sociaalnetwerksites bieden om hun profielen af te schermen.

7 Daarbij kwam het overigens ook voor dat respondenten mij een vriendschaps- of volgverzoek stuurden. 
ling na, ook offline ken of wel eens ontmoet heb. Daarbij was ik online transparant over mijn identiteit als onderzoeker. Naast persoonlijke foto's valt in de profielen van mijn eigen socialmedia-accounts te lezen dat ik als criminoloog verbonden ben aan de Erasmus Universiteit Rotterdam.

Het gebruik van de berichten, afbeeldingen en video's op social media roept vervolgens de vraag op hoe deze informatie gebruikt kan worden, in het bijzonder als het gaat om publicatie. Een dergelijk dilemma doet zich ook voor als het gaat om offline vormen van etnografisch onderzoek. Het gaat daarbij om ethische afwegingen rondom herkenen herleidbaarheid, waarbij het de taak van de onderzoeker is om er zo veel mogelijk zorg voor te dragen dat respondenten geen nadelige gevolgen ondervinden van hun participatie aan het onderzoek (Van de Bunt 2015). Op social media spelen deze overwegingen evenzeer, maar wordt het complexer vanwege de visuele component: veel jongeren maken immers foto's en video's van zichzelf, en elkaar, en plaatsen deze in veel gevallen op openbaar toegankelijke profielen op internet. Over de manier van het gebruiken van visuele data woeden discussies over ethiek (Vanderveen 2010, p. 406-408). Allen (2015) werpt de terechte vraag op of het anonimiseren van afbeeldingen, iets dat gemeengoed is als het gaat om de verslaglegging van offline onderzoek, geen farce maakt van de visuele dimensie van het onderzoek, omdat het de respondent diens 'stem' ontneemt wanneer foto's worden geretoucheerd of 'geblurd'. In deze bijdrage, en in mijn proefschrift, heb ik tweets geanonimiseerd en gezichten onherkenbaar gemaakt. Een belangrijke overweging daarbij was dat het gaat om afbeeldingen waarop strafbare feiten worden gepleegd, afgebeeld of verbeeld. Ik heb ervoor gekozen om wel de verbeelding van deze gedragingen, zoals wapens, kogels, grote hoeveelheden contant geld, drugs en gestolen goederen te tonen, maar zonder gebruikersnaam of gezicht. Herkenbaarheid van de respondent in kwestie had in dergelijke gevallen geen meerwaarde of functie.

Een laatste beperking hangt samen met het voorgaande thema. Op social media is het lang niet altijd duidelijk of afbeeldingen 'echt' of authentiek zijn. Van Erp e.a. stellen daarnaast de terechte vraag 'of online beweringen ook offline worden waargemaakt' (Van Erp e.a. 2013, p. 333). Social media bieden een dankbaar podium voor vormen van 'impression management' (Goffman 1959), iets dat in het bijzonder zichtbaar wordt als het gaat om online uitingen van straatcultuur 
(Van den Broek 2013). In het geval van de voorbeelden in deze bijdrage is het moeilijk om te achterhalen of we van doen hebben met echte wapens of echt geld en of diegene die de afbeelding plaatst ook diegene is die gefotografeerd is, behoudens de gevallen waarin gezichten of andere duidelijk herkenbare persoonskenmerken zichtbaar zijn. De informatie op social media lijkt in eerste instantie meer te zeggen over de indrukken die respondenten willen overbrengen. Dit vormt een beperking in het analyseren van online praktijken, maar dit geldt in het bijzonder wanneer enkel wordt afgegaan op wat respondenten online doen. Over het algemeen is kwalitatief onderzoek in staat om zicht te geven op het bestaan van verschillen tussen wat mensen zeggen en wat ze doen. In het geval van etnografisch onderzoek kan dit bijvoorbeeld door het combineren van gesprekken met het observeren van gedrag. Social media kunnen hierbij een extra dimensie aanbrengen, die de onderzoeker in staat stelt om een inschatting te maken van de manier waarop posts en poses zich verhouden tot offline praktijken, maar ook andersom.

\section{Conclusie}

De prominente plaats van internet in ons dagelijks leven dwingt tot een reflectie op de rol van online praktijken in wetenschappelijk onderzoek. Het centrale punt dat ik in deze bijdrage heb willen maken, is dat social media diverse relatief laagdrempelige, aanvullende mogelijkheden bieden voor het verzamelen van data en het leggen van contacten met respondenten. De toenemende mobiliteit en virtualisering van het dagelijks leven hebben gevolgen voor het klassieke etnografische uitgangspunt van 'being there'. Het gebruik van social media kent daarbij beperkingen die in het verlengde liggen van discussies rondom selectiviteit en ethiek die opgeld doen in offline vormen van etnografisch onderzoek. Maar bovenal hoop ik dat deze bijdrage heeft laten zien dat het incorporeren van online praktijken onderzoekers in staat stelt om beter recht te doen aan het gegeven dat verhalen, ook criminologisch relevante verhalen, zich niet langer enkel offline afspelen. 


\section{Literatuur}

\section{Adler \& Adler 1998}

P. Adler \& P. Adler, 'Foreword: Moving backward', in: F. Ferrell \& M. Hamm (red.), Ethnography at the edge: Crime, deviance and field research, Boston: Northeastern University Press 1998, p. xiixvi.

\section{Allen 2015}

L. Allen, 'Losing face? Photo-anonymisation and visual research integrity', Visual Studies (30) 2015, afl. 3, p. 295-308.

\section{Van den Broek 2013}

J.B.A. van den Broek, Van de straathoek naar Facebook. Een onderzoek naar het gebruik van social media door jongeren binnen de straatcultuur (ongepubliceerde masterscriptie). Erasmus Universiteit Rotterdam 2013.

\section{Van de Bunt 2015}

H.G. van de Bunt, 'Ethische dilemma's bij criminologisch onderzoek', Tijdschrift over Cultuur en Criminaliteit (5) 2015, afl. 1, p. 55-70.

\section{Van Erp e.a. 2013}

J. van Erp, D.W. Stol \& J. van Wilsem, 'Criminaliteit en criminologie in een gedigitaliseerde wereld', Tijdschrift voor Criminologie (55) 2013, afl. 4, p. 327-341.

\section{Ferrell \& Hamm 1998}

J. Ferrell \& M.S. Hamm, Ethnography at the edge. Crime, deviance, and field research, Boston: Northeastern University Press 1998.

\section{Ferrell e.a. 2015}

J. Ferrell, K. Hayward \& J. Young, Cultural criminology: An invitation, Londen: Sage 2015.

\section{Flick 2010}

U. Flick, 'Kwalitatief onlineonderzoek: gebruik van internet', in: T. Decorte \& D. Zaitch (red.), Kwalitatieve methoden en technieken in de criminologie, Leuven/Den Haag: Acco 2010, p. 407-431.

\section{Van Gemert 1998}

F.H.M. van Gemert, Ieder voor zich. Kansen, cultuur en criminaliteit van Marokkaanse jongens, Amsterdam: Het Spinhuis 1998.

\section{Goffman 1959}

E. Goffman, The presentation of self in everyday life, Harmondsworth, Middelsex: Penguin Books 1959.

\section{Hannerz 2003}

U. Hannerz, 'Being there... and there... and there! Reflections on multi-site ethnography', Ethnography (4) 2003, afl. 2, p. 201-216. 


\section{De Jong 2007}

J.D. de Jong, Kapot moeilijk. Een etnografisch onderzoek naar opvallend delinquent groepsgedrag van 'Marokkaanse' jongens, Amsterdam: Aksant 2007.

\section{De Jong \& Schuilenburg 2006}

A. de Jong \& M. Schuilenburg, Mediapolis. Populaire cultuur en de stad, Rotterdam: Uitgeverij 010, 2006.

\section{Leander \& McKim 2003}

K.M. Leander \& K.K. McKim, "Tracing the everyday "sitings" of adolescents on the Internet: A strategic adaption of ethnography across online and offline spaces', Education, Communication \& Information (3) 2003, afl. 2, p. 211-240.

\section{Murthy 2008}

D. Murthy, 'Digital ethnography: An examination of the use of new technologies for social research', Sociology (42) 2008, afl. 5, p. 837-855.

\section{Roks 2007}

R.A. Roks, 'Het is hier toch geen Amerika?' Reconstructie van de criminele carrière van een Nederlandse 'gangsta' (ongepubliceerde masterscriptie), Erasmus Universiteit Rotterdam 2007.

\section{Roks 2015}

R.A. Roks, 'Never snitch broertje, want de straat hoort het', Ars Aequi (64) 2015, afl. 5, p. 422-425.

\section{Roks 2016}

R.A. Roks, In de h200d. Een eigentijdse etnografie over de inbedding van criminaliteit en identiteit, Rotterdam: Erasmus School of Law 2016.

\section{Schuilenburg e.a. 2011}

M. Schuilenburg, D. Siegel, R. Staring \& R. van Swaaningen, 'Over cultuur en criminaliteit', Tijdschrift over Cultuur \& Criminaliteit 2011, afl. 1, p. 3-17.

\section{Van Stapele 1998}

S. van Stapele, 'Crips', Nieuwe Revu (15) 1998, afl. 3, p. 42-47.

\section{Van Stapele 2003}

S. van Stapele, Crips.nl: 15 jaar gangcultuur in Nederland, Amsterdam: Vassallucci 2003.

\section{Van Stapele 2009}

S. van Stapele, 'Papa is een Crip', Revu (45) 2009, afl. 14, p. 22-28.

\section{Vanderveen 2010}

G. Vanderveen, 'Visuele data en methoden in de criminologie', in: T. Decorte \& D. Zaitch (red.), Kwalitatieve methoden en technieken in de criminologie, Leuven: Acco 2010, p. 380-413.

\section{Wittel 2000}

A. Wittel, 'Ethnography on the move: From field to net to Internet', Forum: Qualitative Sozialforschung/Forum: Qualitative Social Research (1) 2000, afl. 1, www.qualitative-research.net/ index.php/fqs/article/ viewArticle/1131/2517. 
64 Justitiële verkenningen, jrg. 42, nr. 1, 2016

\section{Zaitch e.a. 2010}

D. Zaitch, D. Mortelmans \&

T. Decorte, 'Participerende

observatie in de criminologie', in:

T. Decorte \& D. Zaitch (red.),

Kwalitatieve methoden en tech-

nieken in de criminologie.

Leuven: Acco 2010, p. 257-309. 